\title{
Salvation in Acts 16:16-40: A socio-historical exploration of the Graeco-Roman understanding
}

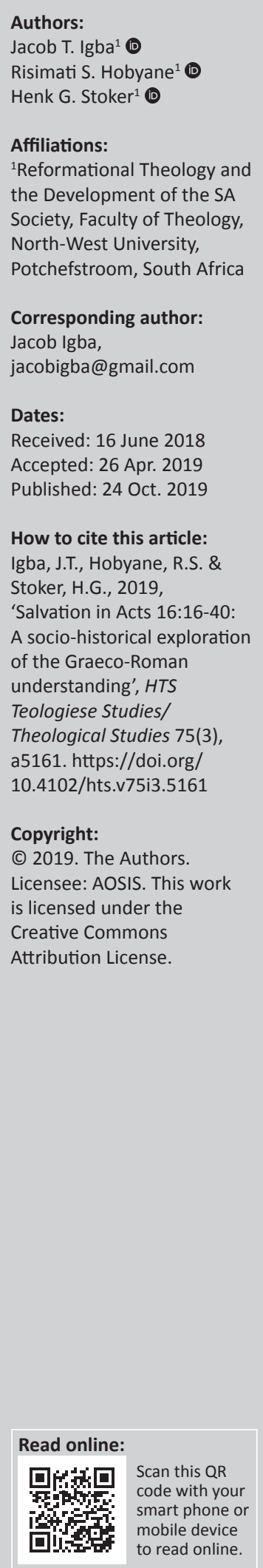

This article demonstrates the value of understanding the socio-historical background of a specific text in the task of interpretation and the search for meaning. This is done here by utilising the socio-historical method in the search for meaning and understanding of the concept of salvation in the narrative about the slave girl in Acts 16. Substantial integration of the understanding of words and concepts at the time of writing the text and the cultural and social background is relevant and leads to an in-depth understanding of the Biblical text and is therefore essential for thorough New Testament studies. Through the socio-historical method, the article explores the Graeco-Roman understanding of salvation as a necessary precursor to arrive at the meaning of salvation in Acts 16. Theos upsistos [Most High God] and the Lukan usage of $\pi v \varepsilon v \tilde{\mu} \alpha \Pi v \theta \omega v \alpha$ [python spirit] are explored in the light of their Graeco-Roman allusion in relation to the girl who was a slave in the narrative of Acts 16. The article argues that Luke's point in the narrative is to expose, engage, challenge and counter the long-held assumptions about what is the meaning of salvation and how to obtain it. The article contributes an exemplification of the use of the socio-historical method towards the broader and in-depth understanding and credible meaning-making of the Acts 16 text. The article challenges assumptions about the point of the text in the narrative of Acts 16 and opens up possibilities for further interpretation that could be found meaningful to modern-day interpreters of the text.

Keywords: Acts 16; Salvation; Socio-historical; Graeco-Roman; Theos upsistos; Python spirit.

\section{Introduction}

Kauppi (2006:8) opines that in some contemporary New Testament scholarship it is not uncommon to find the practice where Graeco-Roman religion is either altogether ignored or misinterpreted in the task of interpretation, especially when dealing with texts that are situated within the Graeco-Roman context. ${ }^{1}$ He therefore sets out to remedy that. His monograph, Foreign but Familiar Gods, published in 2006, stands out as a thorough attempt towards investigating what he refers to as 'overlooked references' to Graeco-Roman religion in Acts. In a significant way, Kauppi advances similar attempts earlier made by scholars who studied Luke's use of Graeco-Roman religions, such as Tremel (1981), Wildhaber (1987), Grant (1986), Soffe (1986), Klauck (1994) and Gill (1994).

In his work, Kauppi pays attention to various allusions in Acts that may be foreign to the modernday readers but are familiar to Graeco-Romans within their religious experience. In the monograph, Kauppi focuses his investigation on places that make mention of, or with allusion to oracles and divination, the imperial cult, the Graeco-Roman sacrificial system, Athenian civic foundation mythology as seen in Aeschylus' Eumenides, the Artemis cult, votive offerings, $\Delta$ 1o $\pi \varepsilon \tau$ '́ objects,

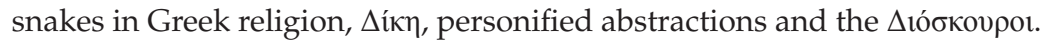

Although it is extensive, Kauppi's monograph fails to consider the important discussion on the origins of some important concepts like the Theos upsistos [Most High God] in Acts 16. He also did not account for the nuanced meaning that could emerge from understanding the origin of the concept, bearing in mind that such nuance could impact the understanding of what salvation means from a Lukan point of view.

The question of the origins of the concept has remained largely unresolved among the majority of scholars although the question remains important as it impacts the understanding and meaning of the text that this research is concerned with.

1.A recent interpretive analysis of Acts 16:16 from the perspective of studies in the field of disability by Valentine (2018:352-368) shows an interesting approach that confirms Kauppi's concern and charge against contemporary new scholarship. 
An investigation into the Graeco-Roman religious context is therefore necessary towards credibly reconstructing the meaning of the text under consideration. This approach takes into account the fact that behind the Luke-Acts narrative there is a shared social, cultural and religious knowledge and assumptions between the author and the first audience. Exploring such shared assumptions therefore remains vital especially for a modern audience seeking to interpret the text. The investigation here will help to avoid the charge by Kauppi as noted above. This is important for this research because the narrative in Acts 16, which is the focus here, took place within the broader Graeco-Roman context.

This investigation aims to show the Graeco-Roman understanding of salvation and Luke's point in the narrative of Acts 16.

\section{Methodology}

This research is undergirded by the socio-historical method. Socio-historical method as utilised here relates to the socioscientific method, but differs in ways explained below. The use of the socio-historical method within Biblical studies can be traced back to Shirley Jackson Case, although it was further developed and defined by others. According to Meeks (2003:2-7), this method seriously takes into account the available data regarding the social world of the first Christians together with the Biblical text and utilises both towards 'constructing interpretations and challenging established constructions'.

Van Staden and Van Aarde (1991:56) provide a useful survey of major works and how the socio-scientific method has been employed by Biblical scholars in the quest of finding legitimate means to apply sociological, anthropological and psychological principles to the texts of the Bible for interpretation. They argue that what happens largely in this growing methodological field is social description, which differs from socio-scientific explanation. Following Best (1983:185), Van Staden and Van Aarde (1991:57) ${ }^{2}$ assert that a true reflection of the use of the socio-scientific method necessarily requires the use of the tools and techniques of modern sociological study to 'probe the inner dynamics of the early Christian movement'. ${ }^{3}$ This is precisely where the socio-scientific method differs from the socio-historical method as used here. Although a relationship exists between the two methods in that both are concerned with the social and historical backgrounds of the text, the socio-scientific method executes the interpretive task using modern sociological or scientific interpretive grid or theories without sufficient attention to the culture and context of the 1st century, and, similarly, without sufficient attention to the theological content of the Biblical text (Botha 1990; Van Rensburg 2000). The socio-historical method differs from the socio-scientific method in the way that it better utilises data the field of the social-scientific study of the New Testament'.

3.See Best (1983:181-194) who advocates for, as well as provides a critical outlook of the use of modern sociological tools in approaching the New Testament. from the culture, context and theology of a given text in arriving at the meaning.

Scholars (Gerth \& Mills 1954; Mannheim 1953; Schwartz 1955:134-154) have established that the fundamental assumption underlying the socio-historical method that drives this project is that social structures determine the behaviour of the individual within such structures. An exploration of the understanding of salvation from the viewpoint of the socio-historical milieu within which the narrative of Acts 16 occurred would therefore serve the broad overall purpose of this research, which is the search for the full extent of meaning, significance and implication of salvation in this Biblical narrative.

\section{Salvation in view of the Graeco- Roman religio-cultural context}

As early Christianity grew, it actively engaged the GraecoRoman religio-cultural context within which it existed. ${ }^{4}$ The difference however between the ancient Mediterranean world of the New Testament and the modern world within which the interpretative task is carried out creates a scenario in which it becomes a common place to find New Testament studies that do not adequately take this reality into account. Therefore, paying attention to the conceptual understanding that exists within that cultural context makes justice to a more robust approach in the quest for understanding the meaning of any narrative that finds its origins in that context. Bearing that in mind, the quest for an understanding of the socioreligious and cultural milieu of the Graeco-Roman world in order to trace the conceptual understanding of salvation becomes imperative to this section of the research. Such an understanding, as Hubbard (2013:104) notes, makes possible an interpretation of the text that is able to clearly identify 'where and how the New Testament writers actually were engaging, and often challenging, the everyday assumptions of the world around them'.

\section{Graeco-Roman religious landscape and salvation}

\section{Graeco-Roman religious landscape}

Of the many legacies attributed to Alexander the Great (334-323 BC) in his conquests, the legacy of a permeating influence of Greek culture and religious ideas in the ancient Graeco-Roman world is noted as outstanding. Even though there was no imposition of a singular religious belief, the said influence brought forth a (Hubbard 2013):

Panhellenic religious framework that continued to honour the classical pantheon of ancient Athens, yet without excluding the multitudes of regional deities, local mythologies, and wide spectrum of beliefs and practices among the scores of ethnic groups that composed Hellenistic antiquity. (p. 105)

The fact that the narrative of Acts 16 that this research focuses on specifically finds its occurrence within such a

4.See Hubbard (2013:103) and Neufeld and DeMaris (2010). 
broad-based religious climate necessitates an understanding of that broader religious climate.

As broad-based as the Graeco-Roman religious landscape was, key markers have been identified by scholars (Garland 2001:ix; Hubbard 2013:105-106). These markers point to an identifiable system of religion that highlights the difference between religion in the Graeco-Roman world of the era under review and contemporary religion as understood and subsumed as bedrock of some interpretive assumptions today. Such differentiation deserves to be recast as follows:

- Religion and divinities were not exclusive. Many divinities could be worshiped by individuals or community. This was both expected and encouraged.

- There was no need for conversion from one faith or deity to another, nor were there proselytising or evangelistic tendencies.

- It was primarily concerned not with ethics - how one ought to live - but with how to earn material blessings from the gods and how to avoid their wrath.

- There was no centralised cult, temple or priesthood with translocal authority, nor were there sacred texts to study for training in 'orthodox' dogma.

- It was not experienced as a personal faith in the modern sense of deeply affecting the emotional life or character development of the worshiper.

From the above description, it becomes clear that the ancient Graeco-Roman religion differs substantially from the modern understanding of religion. What this implies for the interpretation of the narrative that concerns this research is that proper attention should be given to the socio-historical and cultural milieu that undergirds the religious views and beliefs as expressed in the narrative of Acts 16.

\section{Graeco-Roman concept of salvation}

As Igba and Stoker (2018:3-9) have shown, apart from the difference in the view of religion between the modern and ancient Graeco-Roman worlds, the assumption that the notion of salvation as understood in both periods being analogous is also problematic and has been questioned by scholars. Adluri (2013) particularly questions that:

What if Greek 'salvation' bespoke a radically different experience than the one we, influenced by over two millennia of Christian upbringing, have come to expect and associate with the term? (pp. 1-26)

He then posits that Greek notions of salvation could be divided into philosophical, theological and religious categories. He goes further to say that for the Greeks, there existed no exact equivalent of the Christian notion of God and because such Christian notions stand diametrically opposed to that of the Greeks, they must be set aside in order to understand what salvation entails in the Graeco-Roman conception. Although there is some merit in Adluri's question and subsequent position, his attempt in placing Greek notions of salvation in separate categories between religion and philosophy is not convincing. According to Igba and Stoker (2018), even though his question makes an important point to the effect that salvation must not be assumed to refer to one and the same thing in Christian theology as in Graeco-Roman thought:

The idea that theology must be separated from philosophy in order to understand Greek notions of salvation is simply inconsistent with the Greco-Roman thought in which theology was inseparable with philosophy. (p. 4)

\section{Graeco-Roman religion, the pantheon of deities and salvation}

Following Kauppi (2006:16-18), Igba and Stoker (2018:3) describe Graeco-Roman religion as not being a monolithic entity, but rather a conglomeration of Greek and Roman ritual practices, personnel (priests, temple attendants, oracles, etc.), individual behaviours ('magic' and the socalled 'popular religion'), schools of thought (philosophy and mystical metaphysics such as Orphism) and localised cults. Graeco-Roman religion can therefore be described as the sum total of religious practices encountered by a GraecoRoman in the daily course of civic life.

According to Igba and Stoker (2018:3), Graeco-Roman religion revolved around cults and a pantheon of gods who had points of beginning in existence and possessed particular endowments and attributes for which their beneficiaries looked to them to provide. Even though they are portrayed in idealistic terms in Greek mythologies, their interconnectedness in practical terms depicted disparate accounts of discord and power play. Depending on the attributes ascribed to a certain deity, benefactors expected such assistance from the deity. Hubbard (2013:109) posits that 'in many ways, the mythology of the ancient Greeks represents a kind of primitive animism organised in a hierarchy and presented with a genealogy'. Essentially then, whether it was help, deliverance, a desired state of being or whatever was needed by a benefactor within the Graeco-Roman religious framework, such a person would petition or look to any of the pantheon of gods that possessed the necessary attribute or endowment that could answer to such a need. Salvation was therefore understood to be available from a plurality of gods. In that setting, salvation is benevolence from the gods that could take the form of rescue, care or healing, among many others things. Hubbard (2013:105-123) provides the following illustration of some of the gods and the scope of their salvific activity towards their devotees:

Principal pan-Hellenic deities

Aphrodite - Goddess of beauty, sexual love and fertility

Apollo-God of music, prophecy, healing and archery

Ares - God of war

Artemis - Goddess of fertility, the wilderness and hunting

Asclepius - God of healing

Athena - Patron deity of Athens; goddess of wisdom, arts and crafts, and war; helper of heroes

Demeter - Goddess of grain

Dionysus - God of wine, merriment and nature 
Eros - God of love

Hades - God of the underworld and the dead

Hecate-Goddess of the underworld and sorcery; also associated with crossroads

Hephaestus - God of fire; blacksmith of the gods; disfigured and banished from Olympus

Hera - Goddess of marriage; wife of Zeus

Hermes - Messenger of the gods; helper of travellers and merchants

Hestia - Goddess of hearth and home

Persephone - Daughter of Zeus and Demeter; queen of the underworld; associated with spring and the fruits of the field

Poseidon - God of the sea and earthquakes

Uranus - God of the sky; father of the Titans

Zeus - Ruler of the gods ${ }^{5}$

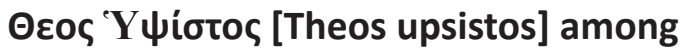 Graeco-Roman deities}

These men are slaves of the Most High God [Theos upsistos] who proclaim to you a way of salvation. (Acts 16:17)

Among the pantheon of pan-Hellenistic deities of prominence in the Macedonian region and of direct importance to this research is the Theos Hypsistos [Most High God]. As pointed out in the Introduction, the Theos Hypsistos, or its variable Theos upsistos, has maintained a place of interest among scholars who are interested in the study of Graeco-Roman notions in Acts 16. The proclamation by the slave girl that Paul and his companion are slaves of the Theos Hypsistos who proclaim a way of salvation bears direct consequence for this interest. The deity is known to be worshipped in the area where the incident in Acts 16 occurred.

The cult of the Theos Hypsistos deity, sometimes referred to as Zeus Hypsistos, is believed to have originated in the Philippi region, as shown by a high concentration of archaeological evidence. Dedicatory inscriptions found throughout Macedonia attest to the worship of this deity in the larger area. When the slave girl in Acts (16:17) declared Paul and Silas to be the slaves of the Theos upsistos who have come to show a way of salvation, a background understanding of the origin of the Theos Hypsistos and the cult of its worshipers would put her assertion in perspective.

To place the historical background of the Theos Hypsistos in perspective, the key question that arises is whether the concept had its origins in the influence of the Jewish diaspora or in pagan Graeco-Roman origins. Scholarly views differ on the question of the historical origins of the notion. Some scholars such as Trebilco (1989), Cook (1925) and Roberts, Skeat and Nock (1936) argue that the notion finds its origin in the syncretic and henotheistic ${ }^{6}$ nature of the ancient Graeco-Roman religion in which a belief in a supreme deity along with other deities existed, while others such as

\section{See Hubbard (2013:105-123)}

6.The belief that holds to the worship of a supreme deity without excluding belief in or the legitimising of the existence of other deities. In that sense, such a belief differs completely from monotheism which holds to the worship of one deity and the exclusion of all other deities. Henotheism differs from Polytheism in that the exclusion of all other deities. Henotheism differs from
Polytheists hold to the worship of multiple supreme deities.
Levinskaya (1996) and Schürer (1897) attribute the origins to early Jews in the diaspora and the spread of their theological influence. Emil Schürer (1897), who is well known for his multi-volume book, History of the Jewish People in the Time of Jesus Christ, was among the earliest to propose that the Theos Hypsistos understanding and eventual cult originated from the influence of the Jews of the diaspora together with the God-fearers.

Tsalampouni (2011:9) utilises data from archaeology and epigraphy for an informed analysis of the Theos Hypsistos cult in Thessoliniki. She attempts to show that a possible link between the Theos Hypsistos cult and the Jewish or Christian presence in the city might have existed. However, she disagrees with Schürer (1897) and proposes that instead of maintaining and upholding the assumption that the understanding originated from the influence of the Jewish monotheistic cult and was the preparatory factor to the Christian message, it should rather be understood the other way round in that (Tsalampouni 2011):

[T] he Jewish synagogue with its monotheistic cult was not the only factor that prepared the pagan world for the acceptance of the Christian message (but) the pagan world itself had got the potential, too, to grasp such ideas and incorporate them in a creative way in its own religious traditions. (p. 9)

She therefore concludes that the Theos Hypsistos notion, cult and its worshippers predated the advent of Jewish communities and Christianity in the Graeco-Roman world, and the cult had already possessed such a notion of the Most High God as could possibly function as a potential bridge between the Gentiles and the Jewish or Christian communities ${ }^{7}$. However, contrary to Schürer (1897), what Tsalampouni does in essence is to show that the Theos Hypsistos notion was of pagan conceptual origin and in fact predates the advent of the Jewish and Christian communities.

Having demonstrated the interchangeability in the usage of the title Theos upsistos and Zeus Upsistos ${ }^{8}$ and having shown such usage as a norm in the Graeco-Roman sphere, Roberts et al. (1936:55-72) proceeded to refute the Jewish diaspora

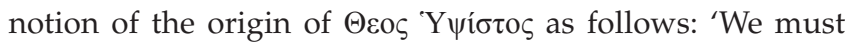
therefore attach some importance to Zeus Hypsistos as a native Greek concept, similar to Zeus Hypsistos who was worshipped in half a dozen places' (Roberts et al. 1936:60).

Considering the nature of evidence by Roberts et al. (1936) and others above, it is plausible to safely draw the

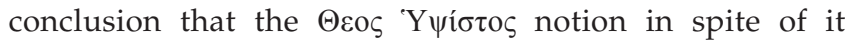
bearing some semblance with the Jewish God is in fact of non-Jewish origin. The ambiguity of usage by the slave girl in Acts 16 and its reflection of the Graeco-Roman henotheistic tendency as discussed earlier stands in

7.The importance of finding a bridge in proclaiming the message of salvation into unknown contexts has been well argued by Stoker (2017:192). Using 2 Corinthians 10:3-5, Stoker discusses the basic aspects of apologetics that could be utilised.

8.'Where Zeus Hypsistos and Theos Hypsistos exist side by side, the Zeus form is the earlier and Theos Hypsistos may be an un-official synonym for him (as elsewhere for other gods)' (Roberts 1936:59). 
opposition to the Jewish unambiguous monotheistic ideas of God, which additionally strengthens the argument for a non-Jewish origin. Furthermore, it is highly unlikely that the actual authorial Graeco-Roman audiences ${ }^{9}$ would

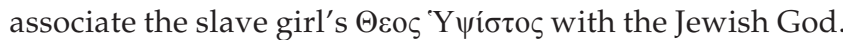
An understanding of Delphi (with whom the slave girl is associated) and the Delphic oracular activities as set out below further buttresses the above conclusion.

\section{Delphi in Graeco-Roman oracular activities}

The oracle neither conceals nor reveals, but indicates Heraclitus in Plutarch, Moralia 404D ${ }^{10}$

Prominent activities in the practice of religion in the GraecoRoman world included the consultation of oracles in the temples, divination, astrology and magic. Among the key places with temples where such oracular activities were carried out was Delphi. In antiquity, Delphi was well known as the central oracular place for seeking divine revelation and guidance. Consulting the oracle on various issues concerning military campaigns, diplomacy, disputes or other personal issues was a common practice (Hubbard 2013:105-123).

Scott (2014:7-30) claims that the oracle and the sanctuary of the Greek god Apollo at Delphi were known as the 'omphalos' - the 'centre' or 'navel' - of the ancient world for more than 1000 years. According to him, individuals, city leaders and kings came from all over the Mediterranean and beyond to consult Delphi's oracular priestess; to set up monuments to the gods in gold, ivory, bronze, marble and stone; and to take part in athletic and musical competitions. The oracular function at the Delphi sanctuary was usually a role reserved for a female priest, known as the Pythia, who had to be a native of Delphi - otherwise known as a Delphian. The Greek god Apollo was known as the Supreme Being behind the oracular utterances, with the Pythia as the mouthpiece. Questions were put to the god Apollo and answers were received through the Pythia. The god Apollo was reputed for ambiguity in the response that came through the Pythias. ${ }^{11}$

Among a number of accounts, the one that stands out about how the Delphic oracular temple became known as Python is that the god Apollo had to slay the snake called Python to enable him to set up his temple in Delphi. The killing of the python led to the naming of the temple Python, with the female priest known as the Pythia.

Hubbard (2013:117) confirms that Python was the earliest name for Delphi, which points to a connection with the slave girl in Acts 16 who was reported by Luke to have the spirit of Python, the Delphic oracle.

9.See a discussion on the type of audiences and the difference between actual and authorial audience in Igba and Risimati (2018), among others.

10.See Scott (2014).

11.For more details on the selection, preparation and operations of the Pythia and other oracular activities in the Delphic region, see Scott (2014).
What strengthens the connection of the slave girl with the oracle of Delphi is confirmed by the common practice at the time where the oracle was consulted for a price and the indication in the narrative of Acts 16 that points to the fact of the slave girl making money for her owners. Whether she was making money for her owners in other ways than divination remains a question unanswered by the text. What the passage clearly shows is that she was making money for her owners through oracular divination activities.

Evidence provided earlier established that even though some similarity in reference to the Jewish God and the Theos Hypsistos exists, the Graeco-Roman henotheistic tendency is in opposition to the Jewish unambiguous monotheistic ideas of God. This refutes the argument that roots the origins of the Theos upsistos in the Jewish diaspora notion. Furthermore, the established link between the slave girl in Acts 16:16 and the Delphic oracular activities discussed above shows the likely distance in meaning and understanding of salvation between Luke as the narrator of the Acts 16 event and the slave girl along with the Graeco-Roman audience. Luke's

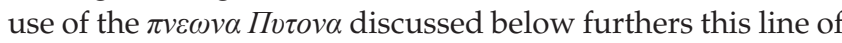
the argument.

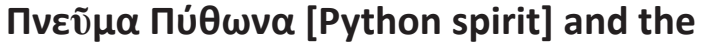 Delphic oracular divination}

Luke in Acts 16:16 narrates that the girl who met Paul and his companion had a $\pi v \varepsilon v \tilde{\mu} \alpha$ Пv́ $\theta \omega v \alpha$ [Python spirit] by which she was able to tell fortunes as a service to those willing to pay for it, through which she brought monetary gain to her master. While the use of $\pi v \varepsilon \tilde{u} \mu \alpha$ [spirit] may not have particular resonance or may not raise the interest of interpreters, the case is different with the use of $\Pi v \theta \omega v \alpha$ [Python]. The ensuing act of exorcising the $\pi v \varepsilon v \tilde{\mu} \alpha$ Пv́ $\theta \omega v \alpha$ [Python spirit] further raises the interest of interpreters of this text. Without subjecting the text to a socio-historical reading, some interpreters see the mention of the $\pi v \varepsilon \tilde{u} \mu \alpha$ $\Pi v \dot{\theta} \omega v \alpha$ [Python spirit] and the resultant 'exorcism' as clear confirmation that the girl was possessed by an evil spirit, which probably explains the displeasure expressed by Paul and the eventual exorcism. The traditional view that interpreters have adopted maintained that an exorcism took place and it must then mean that the girl had an evil spirit. ${ }^{12}$ This view has been challenged as seen below.

We have discussed the Delphi Pythia and established the possibility of the girl being part of a group of people that are of the Delphi-related Graeco-Roman oracular activities. Therefore, the question that arises when this text goes under consideration is whether the Graeco-Romans saw the $\pi v \varepsilon \tilde{v} \mu \alpha$ $\Pi v \dot{\theta} \omega v \alpha$ [Python spirit] as a bad thing from which the girl needed salvation or rescue through exorcism. One could even ask if the slave girl saw herself in that light. The answer to this question has bearing on the implications that could come out of an interpretation of this text, especially for a modern reader.

12.See, for example, the commentary on Acts by Haenchen (1971:495-496) as well as Hans Conzelmann (1987:131), Bruce (1998:361), Johnson (2006:297-298) and Barrett (1998:784-788). 
In the view of Igba and Stoker (2018:5), Luke's usage of the word Пú $\theta \omega v \alpha$ may not be a new or strange concept to grasp or understand within his Graeco-Roman audience. As Lightfoot (2014:219) notes, Luke could rather be seen as using a language that connects to popular belief and culture, a belief within which she would have been popularly known as a $\pi v \theta \omega \lambda \varepsilon \pi \rho \sigma$. Kauppi (2006:19-41) further adds that the usage of the terms $\pi v \varepsilon \tilde{u} \mu \alpha \Pi v \dot{\theta} \theta v$, especially in Acts 16, which translate as a python spirit possibly alludes to the general oracular divination notions of the Graeco-Romans. This could form a basis of assuming that the Graeco-Romans would have no problem seeing the action of the girl as originating in their well-known Greek inductive oracles and oracles of possession or inspiration because of the presence of technical kleromantic vocabulary.

The view that draws the conclusion that the event of the slave girl was indeed an exorcism of an evil spirit therefore becomes contentious, at least from the socio-historical point of approach. Admittedly, there was an expelling of a $\pi v \varepsilon \tilde{v} \mu \alpha$, but as Theissen (1983:87-89) argues, Luke is narrating the expulsion of a $\pi v \varepsilon \tilde{v} \mu \alpha$ and not a demon that was hurtful towards the girl it possessed. To this, Kauppi (2006:28) adds that the slave girl was not demonically possessed by a malevolent spirit, even though her situation was maleficent (at least to modern sensibilities), because she was a slave. From the perspective of the Graeco-Roman audience and other Lukan exorcism narratives, one could argue that there is vast difference with the demonic beings in Luke's Gospel, who make their victims impure and ill, and the spirit in the narrative which is characterised chiefly by its routine inspiration of oracular pronouncements, such that it would have been understood as either beneficial or neutral. As Klutz (2004:243-246) shows, Luke's contemporaries would have

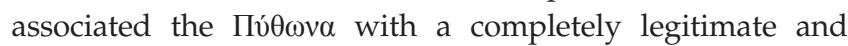
beneficial form of religious activity, namely, the provision of oracles as a service. The reality of cosmic conflict between two powers comes into focus through the reaction of Paul that leads to the departure of the Пú $\theta \omega v \alpha$. The reality of the term $\Pi v \dot{\theta} \omega v$ in particular is stretched and torn between its long history of positive meaning in pagan divinatory practice and its negative contextualisation in the present narrative. ${ }^{13}$ Acknowledging this tension validates the interpretive process, which could lead to credible understanding, resolution and definition especially in places with similar contextual realties.

What the above discussion suggests, as Igba and Stoker (2018:5) note, is that in the mention of the $\pi v \varepsilon \tilde{v} \mu \alpha$ Пv́ $\theta \omega v \alpha$ [Python spirit] and the ensuing exorcism, the focus was not just the exorcism. Luke was rather engaging and challenging a prevalent understanding and an everyday assumption in the Graeco-Roman world around him about the notion of salvation and where it comes from. This does not detract from the reality of cosmic conflict between two powers. It rather brings it sharply into focus, as Klutz (2004:243-246) points out. According to him, through the reaction of Paul 13.See Klutz (2004:243-246). that led to the departure of the Пú $\theta \omega v \alpha$, the reality of the term $\Pi v \dot{\theta} \omega v$ [python] in particular is stretched and torn between its long history of positive meaning through the provision of divination as a legitimate service within the prevalent culture, and its negative portrayal in the present narrative.

\section{Conclusion}

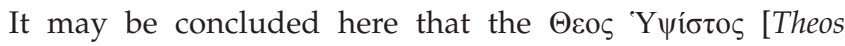
upsistos - Most High God] notion is of a non-Jewish origin. Despite bearing some similarity in reference to the Jewish God, this conclusion is reached considering the ambiguity of its use with respect to the slave girl in Acts 16. Also, its reflection of the Graeco-Roman henotheistic tendency stands in opposition to the Jewish unambiguous monotheistic ideas of God.

Such a faulty notion of the Most High God consequently meant a faulty understanding of salvation by attributing it to the deity.

Furthermore, the evidence presented links the slave girl to the Delphic Pythia. The Graeco-Romans as well as the slave girl therefore had no reason to see the $\pi v \varepsilon \tilde{u} \mu \alpha$ Пv́ $\theta \omega v \alpha$ [Python spirit] as something bad from which the girl needed salvation or rescue through exorcism. Expelling the $\pi v \varepsilon \tilde{v} \mu \alpha$ was therefore a confrontation against what they thought was good. As Klutz (2004:243-246) suggests, the reality of the term Пú $\theta \omega v$ [python] in the narrative faced the challenge of being stretched and torn between its long history of positive meaning in the prevalent culture and its negative contextualisation in the present narrative.

Other interpreters continue to interpret the passage under the assumption that the $\pi v \varepsilon \tilde{u} \mu \alpha$ Пv́ $\theta \omega v \alpha$ [Python spirit] is problematic in the narrative, causing the reaction of Paul, thereby making the point of the narrative in Acts 16 about the exorcism of an evil spirit from a slave girl. Rather, the case was made that the use of Пú $\theta \omega v$ [python] was Luke's way of using popular language to link the slave girl to the known Delphic Pythia. Luke, as the evidence shows, was engaging as well as challenging the prevalent Graeco-Roman understanding and everyday assumptions about the notion of salvation and where it came from.

\section{Acknowledgements Competing interests}

The authors have declared that no competing interests exist.

\section{Author(s) contributions}

All authors contributed equally to the writing of this article.

\section{Ethical consideration}

This article followed all ethical standards for a research without direct contact with human or animal subjects. 


\section{Funding information}

This research received no specific grant from any funding agency in the public, commercial or not-for-profit sectors.

\section{Data availability statement}

Data sharing is not applicable to this article as no new data were created or analysed in this study.

\section{Disclaimer}

The views and opinions expressed in this article are those of the authors and do not necessarily reflect the official policy or position of any affiliated agency of the authors.

\section{References}

Adluri, V., 2013, Philosophy and salvation in Greek religion, De Gruyter, Berlin.

Barrett, C.K., 1998, A critical and exegetical commentary on the Acts of the Apostles, vol. II, pp. 784-788, T\&T Clark, Edinburgh.

Best, T.F., 1983, 'The sociological study of the New Testament: Promise and peril of a new discipline', Scottish Journal of Theology 36(2), 181-194. https://doi.org/ 10.1017/S0036930600029367

Botha, J., 1990, Semeion: 'n Inleiding tot die interpretasie van die Griekse Nuwe Testament, NG Kerkuitgewery, Pretoria.

Bruce, F.F., 1988, The book of the Acts, New International Commentary on the New Testament, p. 361, Eerdmans, Grand Rapids, MI.

Conzelmann, H., 1987, Acts, Hermeneia, Fortress Press, Philadelphia, PA.

Cook, A.B., 1925, Zeus: A study in ancient religion, Cambridge University Press, Cambridge. Garland, R., 2001, Religion and the Greeks, Duckworth, London.

Gerth, H. \& Mills, C.W., 1954, Character and social structure: The psychology of social institutions, Routledge, London.

Gill, D.W.J., 1994, 'Acts and roman religion, a religion in a local setting', in W.J. Gill David \& C. Gempf (eds.), The book of Acts in its Graeco-Roman setting, vol. 2, pp. 79-10, Eerdmans, Grand Rapids, MI.

Grant, R.M., 1986, Gods and the one God, Westminster Press, Philadelphia, PA. Haenchen, E., 1971, The Acts of the Apostles, a commentary, Blackwell, Oxford.

Hubbard, M.V., 2013, 'Greek religion', in J.B. Green \& L.M. McDonald (eds.), The world of the New Testament: Cultural, social, and historical contexts, pp. 105-123, Bake Academic, Grand Rapids, MI.

Igba, J.T. \& Stoker, H.G., 2018, 'Salvation in Acts 16: Meaning and missional implication derived from the sociohistorical method', Verbum et Ecclesia 39(1), a1895. https://doi.org/10.4102/ve.v39i1.1895

Igba, J. \& Risimati, H., 2018, 'Salvation in Acts 16: Socio-historical method as a proposed interpretive methodological framework'. The South African Baptist Journal of Theology 27, 106-124.
Johnson, L.T., 2006, The Acts of the Apostles, pp. 297-298, Liturgical Press, Collegeville, MN.

Kauppi, L.A., 2006, Foreign but familiar Gods: Greco-Romans read religion in Acts, T\&T Clark International, London.

Klauck, H., 1994, 'With Paul in Paphos and Lystra. Magic and paganism in the Acts of the Apostles', Neotestamentica 28(1), 93-108.

Klutz, T., 2004, The exorcism stories in Luke-Acts: A socio-stylistic reading, Cambridge University Press, Cambridge.

Levinskaya, I., 1996, The book of Acts in its diaspora setting, The book of Acts in its first century setting 5, Eerdmans, Grand Rapids, MI.

Lightfoot, J.B., Witherington, B. III \& Still, T.D., 2014, The Acts of the Apostles: A newly discovered commentary, IVP Academic, Downers Grove, IL.

Meeks, W.A., 2003, The first urban Christians: The social world of the apostle Paul, 2nd edn., Yale University Press, New Haven, CT.

Neufeld, D. \& DeMaris, R.E., 2010, Understanding the social world of the New Testament, Routledge, London.

Roberts, C.H., Skeat, T.C. \& Nock, A.D., 1936, 'The gild of Zeus Hypsistos', Harvard Theological Review 29(1), 39-88. https://doi.org/10.1017/S0017816000033198

Schürer, E., 1897, A history of the Jewish people in the time of Jesus Christ, T\&T Clark, Edinburgh.

Schwartz, B., 1955, 'The socio-historic approach', World Politics 8(1), 134-145. https://doi.org/10.2307/2009102

Scott, M., 2014, Delphi: A history of the center of the ancient world, pp. 7-30, Princeton University Press, Princeton.

Soffe, G., 1986, 'Christians, Jews and Pagans in the Acts of the Apostles', in M. Henig \& A. King (eds.), Pagan Gods and shrines of the Roman empire, pp. 239-256, Oxford University Committee for Archaeology, Oxford.

Stoker, H.G., 2017, 'Facing the apologetic challenges of contemporary scientific atheism', Unio Cum Christo 3(2), 185-201. https://doi.org/10.35285/ucc3.2.2017. art11

Theissen, G., 1983, The miracle stories of the early Christian tradition, Fortress Press, Philadelphia, PA.

Trebilco, P.R., 1989, 'Paul and Silas - "Servants of the most high God" (Acts 16.16-18)', Journal for the Study of the New Testament 11(36), 51-73. https://doi.org/ $10.1177 / 0142064 \times 8901103604$

Tremel, B., 1981, 'Voie du salut et religion populaire. Paul et Luc face au resque de paganisa-tion', Lumiere et Vie 30, 87-108.

Tsalampouni, E., 2011, The cult of Theos Hypsistos in Roman Thessalonica and the first Christian community of the city, SBL International Meeting, London, July 07, 2011.

Valentine, K.E., 2018, 'Reading the slave girl of acts 16:16-18 in light of enslavement and disability', Biblical Interpretation 26(3), 352-368. https://doi.org/10.1163/ 15685152-00263P04

Van Rensburg, J.J., 2000, 'Dekor of konteks? Die verdiskontering van sosio-historiese gegewens in interpretasie van ' $\mathrm{n}$ Nuwe Testament-teks vir die prediking en pastoraat, geillustreer aan die hand van die 1 Petrus-brief', Verbum et Ecclesia 21(3), 18. https://doi.org/10.4102/ve.v21i3.640

Van Staden, P. \& Van Aarde, A., 1991, 'Social description or social-scientific interpretation? A survey of modern scholarship', HTS Teologiese Studies/ Theological Studies 47(1), 55-87. https://doi.org/10.4102/hts.v47i1.2353

Wildhaber, B., 1987, Paganisme populaire et predication apostolique, d'apres Vexegese de quelques sequences des Actes, Labor et Fides, Geneva. 